\title{
Does early-career underemployment impact future career success? A path dependency perspective
}

Citation for published version (APA):

Verbruggen, M., van Emmerik, H., van Gils, A. E. J., Meng, C. M., \& de Grip, A. (2015). Does early-career underemployment impact future career success? A path dependency perspective. Journal of Vocational Behavior, 90, 101-110. https://doi.org/10.1016/j.jvb.2015.08.002

Document status and date:

Published: 01/10/2015

DOI:

10.1016/j.jvb.2015.08.002

Document Version:

Publisher's PDF, also known as Version of record

Document license:

Taverne

Please check the document version of this publication:

- A submitted manuscript is the version of the article upon submission and before peer-review. There can be important differences between the submitted version and the official published version of record.

People interested in the research are advised to contact the author for the final version of the publication, or visit the DOI to the publisher's website.

- The final author version and the galley proof are versions of the publication after peer review.

- The final published version features the final layout of the paper including the volume, issue and page numbers.

Link to publication

\footnotetext{
General rights rights.

- You may freely distribute the URL identifying the publication in the public portal. please follow below link for the End User Agreement:

www.umlib.nl/taverne-license

Take down policy

If you believe that this document breaches copyright please contact us at:

repository@maastrichtuniversity.nl

providing details and we will investigate your claim.
}

Copyright and moral rights for the publications made accessible in the public portal are retained by the authors and/or other copyright owners and it is a condition of accessing publications that users recognise and abide by the legal requirements associated with these

- Users may download and print one copy of any publication from the public portal for the purpose of private study or research.

- You may not further distribute the material or use it for any profit-making activity or commercial gain

If the publication is distributed under the terms of Article $25 \mathrm{fa}$ of the Dutch Copyright Act, indicated by the "Taverne" license above, 
Monograph

\title{
Does early-career underemployment impact future career success? A path dependency perspective
}

\author{
Marijke Verbruggen ${ }^{\mathrm{a}, *}$, Hetty van Emmerik ${ }^{\mathrm{b}}$, Anita Van Gils ${ }^{\mathrm{b}}$, Christoph Meng ${ }^{\mathrm{c}}$, Andries de Grip ${ }^{\mathrm{c}}$ \\ a Faculty of Economics and Business, KU Leuven, Belgium, Naamsestraat 69, 3000 Leuven, Belgium \\ ${ }^{\mathrm{b}}$ School of Business and Economics, Maastricht University, The Netherlands \\ ${ }^{c}$ ROA, School of Business and Economics, Maastricht University, The Netherlands
}

\section{A R T I C L E I N F O}

\section{Article history:}

Received 29 May 2015

Received in revised form 13 August 2015

Accepted 14 August 2015

Available online 17 August 2015

\section{Keywords:}

Level underemployment

Content underemployment

Contingent employment

Salary

Job satisfaction

Path-dependency

\begin{abstract}
A B S T R A C T
Whereas many studies have shown that underemployed people experience lower objective career success and lower subjective career success while being underemployed, little research has been done on the lasting effects of underemployment. This study addresses the role of time in career success research by examining the impact of level underemployment, content underemployment and contingent employment on subsequent objective (i.e. salary) and subjective career success (i.e. job satisfaction). Our 10-year longitudinal dataset of 335 Dutch university graduates permits us to examine the impact of preceding underemployment as well as the specific timing of the underemployment in one's career. The multilevel analysis results illustrate that level and contingent underemployment have a negative impact on future pay, whereas content underemployment negatively affects job satisfaction five years later. In addition, for level underemployment also the timing turns out to matter, suggesting that the signal that it sends to employers may differ depending on when in one's career it happened. Taken together, these findings point to the importance of using a path-dependency perspective when trying to understand people's career success.
\end{abstract}

(c) 2015 Elsevier Inc. All rights reserved.

\section{Introduction}

In recent years, the number of people graduating from higher education has increased rapidly all over the world (Scurry \& Blenkinskopp, 2011). However, a decrease in flexibility on the labor market, due to a turbulent state of the economy and the enduring economic crisis (Thompson, Shea, Sikora, Perrewé, \& Ferris, 2013), has resulted in a larger mismatch between labor supply and labor demand for graduate students (Scurry \& Blenkinskopp, 2011). Graduates are therefore increasingly confronted with the risk of underemployment, i.e. employment which is, in some way, of inferior quality than could be expected given one's educational level, skills or experience (Feldman, 1996). Graduates often accept an underemployed job to avoid unemployment and to get some work experience, but without necessarily being aware of the potential negative consequences. Underemployment has frequently been related to lower objective (e.g. lower pay) and subjective (e.g. lower job satisfaction) career success as well as to poorer psychological and physical health (e.g. McKee-Ryan \& Harvey, 2011; Thompson et al., 2013). Apart from these immediate consequences, there are also indications that underemployment could have lasting effects on people's career (Baert, Cockx, \& Verhaest, 2012; Verhaest \& Omey, 2009). The few studies on this topic have shown that underemployment may limit a person's further human capital development

\footnotetext{
* Corresponding author at: Faculty of Economics and Business, KU Leuven, Belgium, Naamsestraat 69, 3000 Leuven, Belgium.

E-mail addresses: Marijke.verbruggen@kuleuven.be (M. Verbruggen), h.vanemmerik@maastrichtuniversity.nl (H.van Emmerik), a.vangils@maastrichtuniversity.nl (A. Van Gils), c.meng@maastrichtuniversity.nl (C. Meng), a.degrip@maastrichtuniversity.nl (A. de Grip).
} 
(Baert et al., 2012; de Grip, Bosma, Willems, \& van Boxtel, 2008) and increases the risk of locking employees into underemployed positions later in their career (Baert et al., 2012; McCormick, 1990).

In this study, we add to the latter line of research by examining whether underemployment has an impact on graduates' subsequent objective career success and subjective career success, and this under control of how their career evolved over time (e.g., whether they have left underemployment or not). We examine the most common forms of underemployment among graduates, namely level, content and contingent employment (Feldman \& Turnley, 1995; Scurry \& Blenkinskopp, 2011). Level underemployment - or "overeducation" - implies employment in a job that in a formal sense is below one's educational level (Allen \& van der Velden, 2001). Content underemployment - or horizontal mismatch - refers to employment outside one's field of education (Meng, 2006; Verhaest, Sellami, \& Van der Velde, in press). Though working outside one's field of education does not necessarily equal a lower level of skills required in the occupation, it does imply that a graduate's discipline-specific skills acquired in education are underutilized (Meng, 2006). Contingent underemployment refers to employment which is temporary in nature, like fixed-term contracts or temporary agency work, and which therefore involves a higher level of insecurity than permanent employment (Bergstrom \& Storrie, 2003). Building on earlier research indicating that underemployed people tend to earn less and are on average less satisfied while they are underemployed (Allen \& van der Velden, 2001; Verhaest \& Omey, 2009), we suggest that due to career path dependency, these graduates also run the risk of lower pay and lower job satisfaction later in their career - even if they have left underemployment in the meantime. In addition, we expect that the timing of the underemployment matters, with underemployment immediately after graduation being less harmful (i.e., implying a less strong stigma) than being underemployed a few years later. We test these hypotheses using three-wave information from Dutch employees that graduated ten years ago.

This paper makes several contributions to the literature. First and most importantly, we apply a longitudinal approach and examine whether underemployment in early career stages has an impact on objective career success and subjective career success in a later stage. If underemployment in one's early career has lasting negative consequences for people's future career success (irrespectively of whether they have left underemployment or not), it becomes of utmost importance to better recognize and remedy early-career underemployment. Second, we explicitly model the role of time by examining its moderating effect on the 'underemploymentsubsequent career success' relationship. In that way, we acknowledge that the impact of a career step (here: having an underemployed job) may depend on when it happened in one's career (Spivey, 2005). Thirdly, we make a distinction between three important types of underemployment among graduates, i.e., (1) level underemployment, (2) content underemployment, and (3) contingent employment on both objective career success and subjective career outcomes. As different types of underemployment tend to be correlated (Feldman \& Turnley, 1995), analyzing these three forms simultaneously enables us to better attribute the impact to the specific type of underemployment and to rule out that the impact of one type of underemployment is actually due to one the other types, a risk which is present in studies focusing on one type of underemployment only (McKee-Ryan \& Harvey, 2011).

\section{Underemployment and subsequent career success}

\subsection{Career success and underemployment}

Career success can be defined as the accomplishment of desirable work-related outcomes over time (Arthur, Khapova, \& Wilderom, 2005). Objective career success refers to those facets of career success that are tangible and can be observed by others, like pay, the number of promotions and job level (Heslin, 2005). Subjective career success refers to the satisfaction that employees derive from their work and is generally operationalized by job satisfaction or career satisfaction (Heslin, 2005). As both objective career success and subjective career success have been shown to contribute to people's well-being and to organizational success (Pachulicz, Schmitt, \& Kuljanin, 2008), career success is among the most important outcome variables in career research.

Several earlier studies have found negative cross-sectional correlations between various types of underemployment on the one hand and salary and job satisfaction on the other hand. (e.g. Allen \& van der Velden, 2001; Verhaest \& Omey, 2009). Yet, little is known about the impact of underemployment on people's later career success. However, this information adds value, both for individuals considering accepting an underemployed job, and for policy makers who often stimulate young graduates to get a job as quickly as possible in order to lower youth unemployment rates. It seems an entirely different dilemma whether or not to accept a job - or stimulate young people to do so - when it implies less pay and less job satisfaction for the time being, than to accept a job which is both less paid and less satisfying now and seriously hampers one's future career success prospects - even if they are then no longer underemployed.

The lack of insight into the lasting impact of underemployment is for a large part related to methodological issues. Not only are many studies on the outcomes of underemployment cross-sectional in nature (Tsai, 2010), the studies that are longitudinal often keep focusing on between-individual cross-sectional relationships while using their longitudinal design to apply more sophisticated estimation techniques (e.g. Tsai, 2010) or examine evolutions in this cross-sectional relationship over time or between cohorts (e.g. Daly, Buchel, \& Duncan, 2000). Though extremely valuable, these studies are hardly informative about dynamic or sequential within-individual processes.

In addition, underemployment studies generally use theoretical perspectives that aim to explain associations between underemployment and outcomes from a cross-sectional perspective, without including the effects of time. Indeed, a recent review of the underemployment literature (McKee-Ryan \& Harvey, 2011) showed that the four theoretical perspectives which are used most frequently to study the impact of underemployment all focus on explaining cross-sectional relationships. First, human capital theory (Becker, 1993) explicates how a fit between human capital and job requirements results in effective labor utilization and efficiency at a specific moment in time. Second, person-environment fit models (Allen \& van der Velden, 2001; Edwards, 1991; Meng, 2006) define underemployment outcomes in terms of present lack of fit between employees' abilities or competences and job requirements, resulting in the negative outcomes 
associated with underemployment. Third, relative deprivation theory (Feldman, Leana, \& Bolino, 2002) relates underemployment to an employee's current experience that (s)he deserves a better job than the current one. Finally, coping and control theory of reemployment (Latack, Kinicki, \& Prussia, 1995) sees current underemployment as a sign of low-quality reemployment for previously unemployed workers, who tend to compare their current situation with the job they lost. Although all four theoretical perspectives provide insightful results, they do not include a specific role for time. Hence, given our focus on lasting effects of underemployment and our longitudinal research approach, we need additional theoretical concepts to hypothesize on the lasting effects of underemployment. We therefore introduce the concept of career path-dependency.

\subsection{A path-dependency perspective}

Path-dependency refers to the previous history of individuals to influence current options and success (Bernhardt, Morris, Handcock, \& Scott, 2001; Sampson \& Laub, 1997). Applied to careers, this implies that the (job) choices and steps people make in the first few years of their career may modify their future career possibilities and in that way their subsequent career success. In his tournament model, Rosenbaum (1979) also advocates path dependency by proposing that quick promotions at the beginning of a career have a durable positive effect on further career success. Similarly, but conversely, we expect that underemployment in one's early career may hamper one' subsequent career success, even if one already left underemployment.

There are several explanations why career path dependency may occur in case of underemployment. Though it is beyond the scope of this study to test these explanations, we believe that it is important to discuss them in order to understand why this phenomenon could take place.

Labeling theory offers a first explanation for path dependency of underemployment. By accepting an underemployment job, people risk to get (rightly or not) labeled as less competent and/or less motivated than those adequately employed, a process which labeling theorists have conceptualized as "stigmatizing" (Paternoster \& Iovanni, 1989). McCormick (1990) even argued that level underemployment (or overeducation), one of the three forms of underemployment we include in this study, could act as a stronger negative signal to employers than unemployment. In addition, these employees may start labeling themselves as less competent, either influenced by the external labeling processes or in an attempt to justify their own career choice. This self-labeling may affect underemployed individuals' self-efficacy and influence their social contacts (Pedulla \& Newman, 2011; Prause \& Dooley, 1997). As both employer's perceptions and individual's self-efficacy and social networks affect people's career success (Seibert, Kraimer, \& Liden, 2001; Verbruggen \& Sels, 2010), early career underemployment may set in motion dynamic processes that lower their subsequent salary and job satisfaction.

A second explanation for the path dependency of underemployment lies in human capital development. Underemployment may limit a person's opportunity to build up human capital and may therefore limit one's subsequent career success. Not only are underemployed jobs often less complex and less challenging (Allen \& van der Velden, 2001), people in underemployment may also be offered less training opportunities. Research has for instance found training opportunities to be fewer for people who are in level underemployment (Büchel \& Mertens, 2004) and for employees in contingent employment (Greenhalgh \& Mavrotas, 1996). Yet, Heijke, Meng, and Ris (2003) found no difference in training opportunities for employees employed outside their field of education. But since training for this group often mainly concentrates on acquiring the skills that would otherwise have been learned through formal education (Heijke et al., 2003), also employees who are in content underemployment may be disadvantaged in their human capital development. In addition, underemployed individuals may also experience a loss in value of their initial competencies. de Grip et al. (2008) found, for instance, that having a job which is below one's educational level (i.e., level of underemployment or overeducation) for at least six years ultimately resulted in cognitive decline in terms of memory, cognitive flexibility and verbal fluency. Since human capital development is associated with higher pay increase (Becker, 1993) and a higher likelihood of getting a better (e.g. more interesting or satisfying) job (Pergamit \& Veum, 1999), this suggests potential long-term disadvantages of initial underemployment.

Finally, also structural aspects of the labor market and of organizations may cause early underemployment to limit a person's subsequent career success (Doeringer \& Piore, 1971). For instance, the dual labor market theory argues that the labor market is segmented into "good jobs" and "bad jobs", with simply very few mobility possibilities between both types of jobs. In addition, organizations often work with fixed career paths, with individuals who are not in the right entry job being excluded from further patterns of promotion. This may also explain why having an underemployed initial job may limit people's subsequent career success.

Based on the arguments, we predict:

Hypothesis 1a. Underemployment has a negative impact on subsequent pay.

Hypothesis 1b. Underemployment has a negative impact on subsequent job satisfaction.

\subsection{Moderating role of timing}

In addition, we expect that the negative impact of underemployment on subsequent career success will become stronger over time. That is, we expect that underemployment immediately after graduation will have a less strong impact on subsequent career success than (still) being underemployed a few years later. This can be explained by the fact that underemployment immediately after graduation is rather frequent (Baert et al., 2012; Béduwé \& Giret, 2011) and can be considered to be a stepping stone towards adequate employment (Baert et al., 2012). However, later in the career, this stepping stone effect will diminish (Baert et al., 2012; 
Carroll \& Tani, 2013). Underemployment later in one's career may therefore be associated with a stronger negative signal and may thus have a more negative impact on people's subsequent career success. This is in line with career timetable theory (Lawrence, 1988), which suggests that there are social norms regarding how an individual's career develops over time and which achievements are appropriate, given one's career stage. The stronger individuals have fallen behind the 'normal' career timetable, the more likely they are viewed unfavorably by organizations, which may limit their subsequent salary and career opportunities (Lam, Ng, \& Feldman, 2012). For this reason, we hypothesize an amplifying impact of time after graduation on the 'underemployment-subsequent career success'-relationship.

Hypothesis 2a. Time after graduation moderates the relationship between underemployment and subsequent pay, in the sense that underemployment later in one's career has a stronger negative impact.

Hypothesis $\mathbf{2 b}$. Time after graduation moderates the relationship between underemployment and subsequent job satisfaction, in the sense that underemployment later in one's career has a stronger negative impact.

\section{Method}

\subsection{Procedure}

For this research project, we used archival data of a large Dutch University about its own alumni. Data were collected with three cohorts of graduates, i.e., the graduates of 1998, 1999 and 2000, at three points in time. A first survey (T1) was collected one year after graduation, so in 1999 for the graduates of 1998, in 2000 for the graduates of 1999 and in 2001 for the graduates of 2000. A second survey (T2) was collected five years after graduation, so in 2003 for the 1998-graduates, in 2004 for the 1999-graduates and in 2005 for the 2000-graduates. Finally, a third survey (T3) was sent to the respondents 10 years after graduation, so in 2008,2009 and 2010 respectively. Of the 1382 respondents at T1, 877 (63.5\%) participated in the second wave and 479 (54.6\%) respondents participated in the third wave.

We performed a dropout analysis to explore to which extent the dropout was random or not. First, we examined differences in means (using independent t-tests) and variances (using Levene's test for equality of variance). We found that the respondents who participated at the three measurement moments were more often female than the dropouts (67\% versus $62 \%$; $\mathrm{p}=.036)$ and that, accordingly, the variance of gender was slightly smaller among the three-wave participants than among the dropouts $\left(\sigma_{\text {three-wave participants }}^{2}=.22\right.$ versus $\left.\sigma_{\text {dropouts }}^{2}=.24 ; \mathrm{p}<.000\right)$. Given these differences, we examined differences in correlations using multivariate regression analysis (Goodman \& Blum, 1996). We used salary at T1 as the dependent variables and gender, age and the underemployment variables at T1 as the explanatory variables. Comparison of the regression coefficients between the two groups showed no significant differences in the coefficients. Therefore, although the dropout was not fully random, the impact of the attrition seems to be limited (Goodman \& Blum, 1996).

The final sample consists of $67 \%$ women and $33 \%$ men. Most respondents studied medicine (27.6\%), health care (26.5) or business (21.5\%). Sixteen percent were mature students (i.e., they had worked first before they started university). The mean age at T1 was 28 years (standard deviation: 5.7 years). Five years after graduation, 75\% of the respondents were living together with a partner and $29 \%$ reported to have children. Ten years after graduation, $88 \%$ were living together with a partner and $67 \%$ had children. The majority of the respondents had a paid job at the three measurement moments (88.6\%).

\subsection{Measures}

Since we were interested in the influence of preceding underemployment, examining the influence of 'preceding underemployment' at T1 does not make sense (as respondents were in school before T1). Therefore, we reorganized our three-wave dataset into a two-wave dataset, focusing on the measurement moments T2 and T3. For these two measurement moments, we created the relevant lagged variables (i.e. preceding underemployment) based on information of these variables as measured at $\mathrm{T}-1$. So, the lagged variables at T2 are measured at T1 and the lagged variables at T3 are measured at T2.

\subsubsection{Career success}

In line with earlier studies (see Heslin, 2005), we used gross salary per hour as an indicator of objective career success. Because the typical high skewness of salary variables, we performed a natural logarithmic transformation on this variable. A natural logarithmic transformation ("ln" or "log e") is used frequently to make positively skewed variables more normally distributed (Dunlap, Chen, \& Greer, 1994). Also in line with earlier studies (see Heslin, 2005), job satisfaction was used as an indicator of subjective career success. Following Verhaest and Omey (2009) and Wooden, Warren, and Drago (2009), we measured job satisfaction by asking respondents how satisfied they were with their current job (1: completely dissatisfied; 5: completely satisfied). Though single item scales have their shortcomings, they are increasingly used to measure satisfaction constructs, like job satisfaction (Wanous, Reichers, \& Hudy, 1997; Wooden et al., 2009). In addition, for job satisfaction, research has shown that single-item scales produce similar effects as facet scores (Wanous et al., 1997). 


\subsubsection{Underemployment}

We included three types of underemployment that are particular prevalent among graduates: level underemployment, content underemployment and contingent employment (Feldman \& Turnley, 1995; Scurry \& Blenkinskopp, 2011). In line with Dolton and Vignoles (2000), we measured level underemployment with the question: "To get your job, what educational level were you required to have?" Response categories were: (1) master's degree (i.e., equivalent to 17 years of education), (2) undergraduate or bachelor's degree (i.e., equivalent to 15 years of education), (3) higher education or tertiary education (i.e., equivalent to 12 years of education) or (4) less education than higher or tertiary education (i.e., equivalent to 10 years of education or less). Following Feldman and Turnley (1995), content underemployment was assessed by asking the respondents whether their job was (1) very well, (2) well enough, (3) moderately or (4) poorly related to their specific college education. Finally, contingent employment was measured with a dummy which is 1 if the respondent indicated $(\mathrm{s})$ he had a temporary job and 0 otherwise. In line with our hypotheses, the explanatory variables included in each regression were the lagged variable of each underemployment dimension (i.e. the score at $\mathrm{T}-1$ ). For each type of underemployment, higher scores point to stronger underemployment.

\subsubsection{Time since graduation}

Time since graduation was, for each individual, five years at wave two and ten years at wave three.

\subsubsection{Control variables}

We controlled for gender $(1=$ woman; $0=$ man), previous salary, unemployment experience since the previous survey (in months) and whether one changed employer since the previous survey ( $1=$ yes; $0=$ no) because these aspect have been related with people's salary and/or job satisfaction (e.g., European Commission, 2014; Ng, Eby, Sorensen, \& Feldman, 2005; Valcour \& Ladge, 2003). In addition, we control for change in underemployment status over time to rule out biased due to correlations between previous and the current underemployment status. We opted for the residualized change score, i.e., the difference between the observed score at $\mathrm{T}$ and the predicted score using the $\mathrm{T}-1$ measure to predict it (MacKinnon, 2008). In doing so, we control for bias due to regression-to-the-mean effects and reduce the risk of multicollinearity with the lagged underemployment variables (MacKinnon, 2008). Positive residualized change scores refer to becoming underemployed, whereas negative residualized change scores refer to leaving underemployment.

\subsection{Analyses}

Multilevel analysis, a hierarchical linear modeling approach, was used to analyze the data as this approach accounts for the dependent nature of the observations (Hox, 2002). Data at the measurement-level (Level 1), e.g. content underemployment, are nested within persons (Level-2) since each person was observed several times. Without controlling for this dependency between observations, we risk to get biased estimates.

For the analyses, 488 measurement points (Level 1) from 335 graduates (Level 2) were available. The dependent variables were (the natural logarithmic transformation of) salary per hour and job satisfaction. To test the hypotheses, the variables were entered in five consecutive steps. After the estimation of the intercept-only model (Null Model), that is the model that contains no explanatory variables, the variable "time since graduation" was added to the model (Model 1) to account for a possible linear trend in the dependent variable. Besides the intercept, also the slope of time was allowed to vary across individuals to account for the possibility that individuals had different rates of change in the dependent variable (Hox, 2002). In Model 2, the control variables were included and in Model 3, the lagged underemployment variables were entered. Finally, in Model 4, interaction terms between the lagged underemployment variables and time were added. The analyses were conducted separately for salary and job satisfaction.

Table 1

Descriptives and correlations among study variables.

\begin{tabular}{|c|c|c|c|c|c|c|c|c|c|c|c|}
\hline & & $\mathrm{m}$ & sd & $\%$ within & 1 & 2 & 3 & 4 & 5 & 6 & 7 \\
\hline \multicolumn{12}{|c|}{ Level-2 variables } \\
\hline 1 & Gender $^{\mathrm{a}}$ & 0.68 & 0.46 & - & - & & & & & & \\
\hline \multicolumn{12}{|c|}{ Level-1 variables } \\
\hline 2 & Months underemployed & 0.33 & 1.33 & $76 \%$ & -.01 & - & & & & & \\
\hline 3 & Having changed employer & 0.48 & 0.44 & $99 \%$ & .05 & .04 & - & & & & \\
\hline 4 & Level underemployment & 1.24 & 0.36 & $66 \%$ & .80 & -.05 & -.03 & - & & & \\
\hline 5 & Content underemployment & 1.64 & 0.67 & $42 \%$ & .10 & .01 & .06 & $.35^{* *}$ & - & & \\
\hline 6 & Contingent employment & 0.29 & 0.34 & $83 \%$ & .10 & $.18^{* *}$ & $.12^{*}$ & -.07 & $-.12^{*}$ & - & \\
\hline 7 & Salary per hour-log & 2.89 & 0.30 & $99 \%$ & $-.28^{* *}$ & $-.16^{*}$ & .02 & $-.23^{* *}$ & $-.13^{*}$ & $-.38^{* *}$ & - \\
\hline 8 & Job satisfaction & 4.06 & 0.79 & $65 \%$ & -.00 & .04 & -.01 & $-.13^{*}$ & $-.24^{* *}$ & -.03 & $.17^{* *}$ \\
\hline
\end{tabular}

Note. $\mathrm{m}=$ mean across individuals, computed using each participant's mean scores. $\mathrm{sd}=$ between-individual variance, computed using each participant's mean scores. \% within = share of the variance in this variable which is due to within-individual variance (only for level-1 variables, which can change over time). Correlations were computed between individuals, using each participant's mean scores. $N=488$ (level 1: observations) and $N=335$ (level 2: individuals).

a $1=$ Female; $0=$ Male.

* $\mathrm{p}<0.05$ (two-tailed).

** $\mathrm{p}<0.01$ (two-tailed). 


\section{Results}

Table 1 presents the descriptive statistics and the correlations. Furthermore, it illustrates how much of the variance in each level 1 -variable is due to within person variation (“\% within”), a figure calculated based on output of a null model-test for each of our variables (i.e., a model without any control variables) (Bryk \& Raudenbush, 1992). About 66\% of the variance in level underemployment, $42 \%$ of the variance in content underemployment and $83 \%$ of the variance in contingent employment can be attributed to within-person variation. For salary, the share of variance due to within-person variation is even up to $99 \%$, and for job satisfaction $65 \%$. These high percentages should not be surprising since we examine career variables within a large time frame of 5 years. Since a person's career tends to develop over time (e.g., people tend to earn more over time), significant changes within individuals were to be expected.

Table 1 also shows a significant positive correlation between level and content underemployment, implying that individuals who have a job below their educational level are also likely to be employed in a field outside their study field. Content underemployment was correlated negatively with contingent employment. So, graduates in content underemployment are less likely to have a temporary contract. Salary was found to correlate negatively with all three underemployment dimensions and job satisfaction was found to have a negative correlation with level and content underemployment, but not with contingent employment.

Table 2 presents the results for the five salary regressions, i.e., the intercept-only model (Null Model), the model that additionally included time (Model 1a), control variables (Model 2a), the lagged underemployment variables (Model 3a) and the interaction terms (Models 4a). Hypothesis 1a stated that graduates who were underemployed at $\mathrm{T}-1$ would have a lower salary in the next time period compared to those who weren't in an underemployed job. As can be seen in Model 3a, we found a significant negative impact of level underemployment and contingent employment on subsequent salary. As the impact of content underemployment was not significant, hypothesis 1a can only partially be confirmed.

Next, we expected that the timing of underemployment would matter. In particular, underemployment later in one's career would have a stronger negative impact on subsequent salary than immediately after graduation. As can be seen in model $4 a$, we found a significant negative interaction between level underemployment and time. The interaction plotted in Fig. 1 illustrates that the impact of underemployment 5 years after graduation on people's subsequent salary is stronger than the impact of underemployment immediately after graduation. Being employed under one's educational level thus seems to have a stronger impact when it happens later in one's career. For content underemployment and contingent employment, we found no significant interaction with time. We can hence only partly confirm hypothesis $2 \mathrm{a}$.

With regard to the control variables (Model 2a), we see that women earn on average less than their male counterparts, that salary tends to rise over time, that salary is higher when one had a higher previous salary and that graduates who changed employer in the past five years earn on average more. In addition, change in underemployment since the previous wave had a negative impact on subsequent salary, an effect found for all three types of underemployment. This implies that salary is affected by the current underemployment status, a finding in line with the many cross-sectional studies on this topic. The number of months of unemployment in the past five years did not have a significant impact on salary above the impact of the other variables that were included (though we have to note that this impact was marginally significant; $\mathrm{p}<.10$ ).

Table 3 shows the results for graduates' job satisfaction. The same five models were tested as for graduates' salary, i.e., the intercept-only model (Null Model), and the models that additionally included time (Model 1b), control variables (Model $2 \mathrm{~b}$ ), the lagged underemployment variables (Model 3b), and the interaction terms with time (Models 4b).

Hypothesis $1 \mathrm{~b}$ stated that underemployment at $\mathrm{T}-1$ would depress subsequent job satisfaction. As can be seen in Model $3 \mathrm{~b}$ (Table 3), we indeed found a significant negative impact of content underemployment. So, graduates who, at $\mathrm{T}-1$, were employed

Table 2

Fixed effects estimates for models predicting hourly salary at time T.

\begin{tabular}{|c|c|c|c|c|c|}
\hline & Null Model & Model 1a & Model 2a & Model 3a & Model 4a \\
\hline Intercept & $3.15(0.02)^{* *}$ & $2.67(0.03)^{* *}$ & $2.05(.10)^{* *}$ & $2.30(.12)^{* *}$ & $2.33(.12)^{* *}$ \\
\hline Time & & $0.07(0.00)^{* *}$ & $0.03(.02)^{* *}$ & $0.04(.01)^{* *}$ & $0.04(.01)^{* *}$ \\
\hline Gender & & & $-0.11(.02)^{* *}$ & $-0.10(.02)^{* *}$ & $-0.10(.02)^{* *}$ \\
\hline Salary per hour $\mathrm{T}_{-1}$ & & & $0.34(.04)^{* *}$ & $0.29(.05)^{* *}$ & $0.29(.05)^{* *}$ \\
\hline Unemployment & & & $-0.01(0.01)$ & $-0.01(0.01)$ & $-0.01(0.01)$ \\
\hline Changed employer & & & $0.05(0.02)^{*}$ & $0.05(0.02)^{*}$ & $0.05(0.02)^{*}$ \\
\hline Change $_{\mathrm{T}-(\mathrm{T}-1)}$ UE1 & & & $-0.08(.03)^{* *}$ & $-0.08(0.03)^{* *}$ & $-0.08(0.03)^{* *}$ \\
\hline Change $_{\mathrm{T}-(\mathrm{T}-1)}$ UE2 & & & $-0.03(.02)^{*}$ & $-0.03(0.02)^{*}$ & $-0.03(0.02)^{*}$ \\
\hline Change $_{\mathrm{T}}-(\mathrm{T}-1)$ UE3 & & & $-0.13(.03)^{* *}$ & $-0.15(0.03)^{* *}$ & $-0.14(0.03)^{* *}$ \\
\hline $\mathrm{UE} 1_{\mathrm{T}-1}$ & & & & $-0.08(0.03)^{* *}$ & $-0.09(0.03)^{* *}$ \\
\hline $\mathrm{UE} 2_{\mathrm{T}-1}$ & & & & $-0.01(0.02)$ & $-0.01(0.02)$ \\
\hline $\mathrm{UE}_{\mathrm{T}}-1$ & & & & $-0.05(0.03)^{*}$ & $-0.05(0.03)^{*}$ \\
\hline $\mathrm{UE} 1_{\mathrm{T}-1} *$ time & & & & & $-0.04(0.01)^{* *}$ \\
\hline $\mathrm{UE}_{\mathrm{T}-1} *$ time & & & & & $0.01(0.01)$ \\
\hline $\mathrm{UE}_{\mathrm{T}-1} *$ time & & & & & $-0.00(0.01)$ \\
\hline$-2 \times \log$ likelih. (df) & $263.69(3)$ & $92.26(6)$ & $17.37(13)$ & $20.02(16)$ & $32.63(19)$ \\
\hline$\Delta-2 \log (\mathrm{df})$ & & $171.42(3)^{* * *}$ & $74.89(7)^{* * *}$ & $2.65(3)$ & $12.61(3)^{*}$ \\
\hline
\end{tabular}

Note: UE1 = Level Underemployment; UE2 = Content Underemployment; UE3 = Contingent Employment.

* $\mathrm{p}<.05$.

** $\mathrm{p}<.01$ 


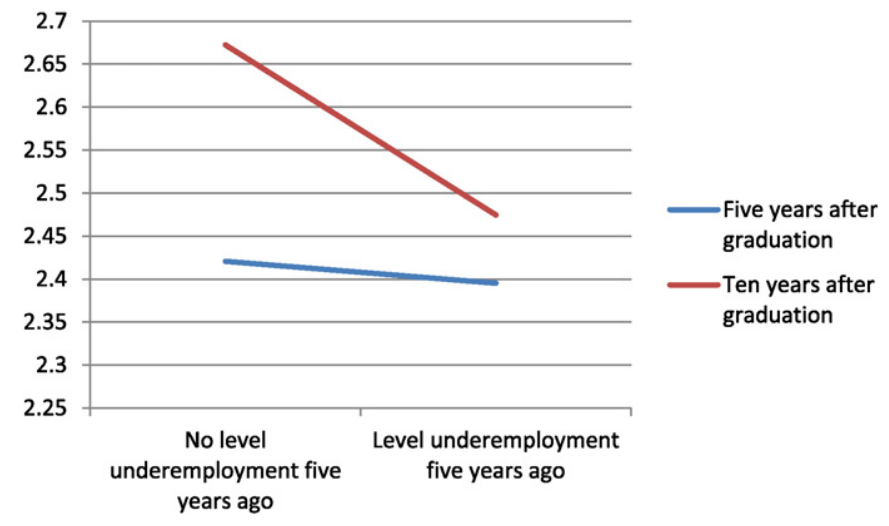

Fig. 1. Salary five years and ten years after graduation, depending on the level underemployment status five years before.

in a job that did not match their specific education were less satisfied with their job 5 years later. We did not find this effect for level underemployment or contingent employment and can therefore only partly confirm hypothesis $1 \mathrm{~b}$. Hypothesis $2 \mathrm{~b}$ stated that the impact of underemployment on subsequent job satisfaction would be stronger for underemployment later in one's career. However, none of the interaction terms with time was found to be significant (see Table 3 - Model 4b). We therefore have to reject hypothesis $2 \mathrm{~b}$. When we have a look at the control variables, we see hardly any influence of the variables included. Only having changed employer and a change in content underemployment status were found to have an impact on job satisfaction.

\section{Discussion}

This study examined the impact of level underemployment, content underemployment and contingent employment on subsequent objective (i.e. salary) and subjective career success (i.e. job satisfaction). In doing so, we applied a career path dependency perspective.

For graduates' objective career success, our results revealed a negative relationship with underemployment five years earlier in their career - and this under control of the change in underemployment status over time, the months of underemployment since the previous survey and change in employer afterwards. In particular, level and contingent underemployment negatively impacted future pay. Although not empirically tested in this project, these results seem to support earlier work of de Grip et al. (2008) who explained that underemployment tends to limit people's opportunity to develop their human capital and earlier research showing that people's pay is often based on the human capital they built up (Becker, 1993). We note that this restraining impact was not found for content underemployment. This may suggest that being employed outside one's field of education does not limit a graduate's human capital formation as long as the level of the job is adequate, which is in line with the results of Heijke et al. (2003).

For graduates' subjective career success, we found a negative impact of content employment on job satisfaction five years later in the career. Since we controlled for change in underemployment and employer afterwards, our results imply that people's satisfaction with their current job depends on their preceding content underemployment status, independently from the fact whether they are

Table 3

Fixed effects estimates for models predicting job satisfaction at time T.

\begin{tabular}{|c|c|c|c|c|c|}
\hline & Null Model & Model 1b & Model 2b & Model 3b & Model 4b \\
\hline Intercept & $4.06(0.04)^{* *}$ & $3.94(0.10)^{* *}$ & $3.57(.32)^{* *}$ & $4.11(.40)^{* *}$ & $4.13(.40)^{* *}$ \\
\hline Time & & $0.02(0.01)$ & $0.01(.02)$ & $0.01(.02)$ & $0.01(.02)$ \\
\hline Gender & & & $0.08(0.09)$ & $0.10(0.09)$ & $0.12(0.10)$ \\
\hline Salary per $\operatorname{hour}_{\mathrm{T}}-1$ & & & $0.13(0.15)$ & $0.02(0.16)$ & $-0.00(0.16)$ \\
\hline Unemployment & & & $0.03(0.03)$ & $0.04(0.03)$ & $0.04(0.03)$ \\
\hline Changed employer & & & $0.15(0.07)^{*}$ & $0.17(0.07)^{*}$ & $0.16(0.07)^{*}$ \\
\hline Change $_{\mathrm{T}-(\mathrm{T}-1)}$ UE1 & & & $-0.12(0.10)$ & $-0.12(0.10)$ & $-0.12(0.10)$ \\
\hline Change $_{\mathrm{T}-(\mathrm{T}-1)}$ UE2 & & & $-0.24(0.05)^{* *}$ & $-0.27(0.05)^{* *}$ & $-0.28(0.06)^{* *}$ \\
\hline Change $_{\mathrm{T}-(\mathrm{T}-1)}$ UE3 & & & $-0.13(0.11)$ & $-0.17(0.11)$ & $-0.13(0.11)$ \\
\hline $\mathrm{UE} 1_{\mathrm{T}-1}$ & & & & $-0.05(0.09)$ & $-0.05(0.09)$ \\
\hline $\mathrm{UE} 2_{\mathrm{T}-1}$ & & & & $-0.13(0.05)^{*}$ & $-0.13(0.05)^{*}$ \\
\hline $\mathrm{UE}_{\mathrm{T}}-1$ & & & & $-0.10(0.09)$ & $-0.10(0.09)$ \\
\hline $\mathrm{UE}_{\mathrm{T}-1} *$ time & & & & & $-0.04(0.04)$ \\
\hline $\mathrm{UE}_{\mathrm{T}-1} *$ time & & & & & $-0.02(0.04)$ \\
\hline $\mathrm{UE}_{\mathrm{T}}-1 *$ time & & & & & $0.06(0.04)$ \\
\hline$-2 \times \log$ likelih. (df) & $1244.42(3)$ & $1244.96(6)$ & $1208.71(13)$ & $1209.33(16)$ & $1217.64(19)$ \\
\hline$\Delta-2 \log (\mathrm{df})$ & & $.53(3)$ & $52.46(11)^{* *}$ & $0.62(3)$ & $8.31(3)^{*}$ \\
\hline
\end{tabular}

Note: UE1 = level underemployment; UE2 = content underemployment; UE3 = contingent employment.

$* \mathrm{p}<.05$.

** $\mathrm{p}<.01$. 
still underemployed or whether they have changed jobs afterwards. Possibly, experiencing content underemployment limits the kind of jobs people subsequently have access to. Not only may recruiters prefer applicants with more domain-specific work experience (KristofBrown, Zimmerman, \& Johnson, 2005), employers may also interpret people's preceding content underemployment as a negative signal with regard to their capabilities or motivation (McCormick, 1990). This may force graduates who experienced content underemployment early in their career to accept jobs that are less in line with their preferences, even though they may not be formally "underemployed". Such a situation can result in a lower job satisfaction.

Finally, we found that for level underemployment the timing of it matters. More specifically, the impact of level underemployment on graduates' subsequent salary was stronger when the underemployment happened (or endured till) later in their career. This finding may be related to the fact that at the start of their career, many graduates accept a job for which they are overeducated, mainly to get out of unemployment or because they hope this job would be a stepping-stone towards more adequate employment (Baert et al., 2012). Therefore, the signal sent from level underemployment at the start of one's career may be only moderately negative. However, when people do not succeed to escape their initial level underemployment or, for some reason, end up in level underemployment later in their career, employers could interpret this as a strong signal of lower competence or lower motivation. This may limit the opportunity to earn more later in one's careers. Overall, this finding is in line with career timetable theory (Lawrence, 1988) and points to the importance of taking the timing (i.e., when people had a specific job) into account to understand graduates' career outcomes.

\subsection{Implications for theory development}

This study illustrates the importance of applying a path-dependency perspective (Bernhardt et al., 2001) to shed light on the role of time in career success research (Spurk, Abele, \& Volmer, 2011). Our findings regarding the impact of underemployment on people's later career success, meanwhile controlling for what happened later in that career, suggest that graduates' early career choices (here: accepting an underemployed job) may limit their subsequent career opportunities and outcomes. Moreover, for level underemployment, also the timing turned out to matter, suggesting that the signal of underemployment sent to employers may differ depending on when in one's career it takes place. Theory development in this field would benefit from not only taking career path variables into account, but also the specific order in which different jobs follow each other, when trying to understand people's career success.

Furthermore, this study contributes to the underemployment literature, as we examined the impact of three underemployment dimensions simultaneously (McKee-Ryan \& Harvey, 2011). Thereby, we reduced the risk of finding spurious effects due to correlations between the different underemployment dimensions and were better able to attribute the effects found to the relevant underemployment dimension. For instance, our findings nuance the assumption present in the literature that content underemployment limits human capital formation and as such automatically has a negative effect on wage (e.g. Borghans \& Golsteyn, 2007). Since we found no impact of preceding content underemployment on pay level when we controlled for level underemployment, our study suggests that content underemployment does not necessarily limit a person's human capital formation as long as the job level is adequate. Remark that at the same time, we found an impact of the change in content underemployment afterwards, which indicates that when people changed to a job outside their field of education later in their career, their built-up human capital loses part of its value, which results in a lower pay. Only by taking into account the different underemployment dimensions simultaneously, this study allowed us to formulate this more precise view on the impact of content underemployment.

Finally, our findings also show that the three underemployment dimensions included in this study, i.e., level underemployment, content underemployment and contingent employment, differ in their effects. In particular, level underemployment and contingent employment are more strongly related with pay level - and thus likely with human capital formation - whereas content underemployment was stronger related to job satisfaction. In addition, also the role of timing and sequence was found to differ between the specific underemployment dimensions. Given these differences, our study underscores the importance of being explicit about the type(s) of underemployment that are studied and warrants against the use of underemployment measure which combine different types of underemployment into a single measure (e.g. Burke, 1997).

\subsection{Implications for practice}

Our study shows that accepting an underemployed job is not without risks for young graduates. Underemployment in the first years after graduation may impact graduates' salary and job satisfaction up till 10 years after graduation. Even if individuals succeed to make the transition to a more suitable job afterwards, part of the differences in wage and job satisfaction seem to sustain. It is therefore important to make graduates aware of these potential consequences; only then can they make careful and well-thought-through first career choices. Important to mention however, is that this study does not provide a complete picture of the consequences of early career underemployment. We did not include potential positive outcomes, such as a shorter job search duration. It is likely that there is a trade-off between the speed of finding employment and the quality of this employment (Baert et al., 2012). For graduates to make truly informed early career choices, more information is needed about this trade-off and about the longer-term career paths and outcomes of opting for underemployment.

The findings of this study are also of interest to policymakers. For a long time, policymakers were particularly interested in reducing unemployment rates. As graduates' speed of finding employment may increase through accepting underemployed jobs, policy makers have taken a positive stand towards this type of employment (e.g. Ministry of Finance, 1998). Increasingly, however, policy makers' view towards underemployment is getting more nuanced. Underemployment is increasingly seen as a signal that the labor market is working inefficiently, with suboptimal returns to educational investments, not only at the individual but also at the societal level. In addition, the negative effects of underemployment on graduates' pay and job satisfaction could be accompanied by increased health 
problems and financial difficulties (e.g. Dooley, Prause, \& Ham-Rowbottom, 2000), which may result in societal costs, like increased health care costs. This is especially likely when, as we found in our study, the effects of underemployment endure over time. This all supports the trend towards a more nuanced view on underemployment among policy makers.

\subsection{Limitations and suggestions for future research}

Some of the limitations of this study could be addressed in future research. Using an archival dataset brings inherently limitations with it. First of all, single-item indicators were used to assess job satisfaction and underemployment. Though this is in line with many other underemployment studies (e.g. Verhaest \& Omey, 2009; Wooden et al., 2009), single-item measures are sometimes questioned for validity and reliability reasons. It is therefore relevant for future research to examine whether our findings hold when multiple-item scales are used.

Second, we only included three underemployment dimensions in our study. Though this is an advantage over many underemployment studies (McKee-Ryan \& Harvey, 2011), more detailed information about underemployment and even more underemployment dimensions (e.g., McKee-Ryan and Harvey (2011) identified no less than eight possible underemployment dimensions) could further enhance knowledge development in this field. Only by examining the impact of different underemployment dimensions together, the underemployment phenomenon can be truly understood in all its facets. Thirdly, we used self-reported measures of underemployment. Since conclusions based on subjective underemployment measures may differ from those based on objectively assessed underemployment (e.g. Verhaest \& Omey, 2010), future research could examine whether objective underemployment results in similar longitudinal effects. Fourth, we focused on only two outcomes, i.e., job satisfaction and salary. Examining other outcomes, such as other job benefits, seems relevant and could give a more comprehensive view on the trade-offs people make when deciding to accept an underemployed job.

Fifth, while the career literature acknowledges the significance of agentic considerations next to structural influences on career choices (Özbilgin et al., 2005), we had no information about the voluntariness of the underemployment over the different time periods. However, the outcomes of underemployment - especially the impact on employees' attitudes, such as lower job satisfaction could depend on the degree to which the graduate had freely chosen to be underemployed or even preferred it over regular employment (McKee-Ryan \& Harvey, 2011; Scurry \& Blenkinskopp, 2011). This might be especially relevant in the Netherlands, as flexible or contingent employment has become common (de Vries \& Wolbers, 2005), among others to combat youth unemployment. Future research would benefit from a more fine-grained analysis of the effect of voluntary versus involuntary underemployment levels.

Finally, although we used theoretical arguments from labeling and human capital development theory to develop our hypotheses, our dataset did not allow us to test these assumptions. Future research might benefit from a qualitative research approach in which the behaviors of a more limited number of underemployed people and the effects of it over a number of years are analyzed in more detail.

\section{Acknowledgments}

We are grateful to the reviewers of the Academy of Management Meeting 2013 Careers Division, the reviewers of the Academy of Management Meeting 2013 Best Applied Paper Award Commission and Mark Levels and Annemarie Kuenn of ROA Research Memorandum (Maastricht University) for their useful comments and suggestions on previous versions of this paper.

\section{References}

Allen, J., \& van der Velden, R. (2001). Educational mismatches versus skill mismatches: Effects on salaries, job satisfaction, and on-the-job search. Oxford Economic Papers, 5, 434-452.

Arthur, M.B., Khapova, S.N., \& Wilderom, C.P. (2005). Career success in a boundaryless career world. Journal of Organizational Behavior, $26,177-202$.

Baert, S., Cockx, B., \& Verhaest, D. (2012). Overeducation at the start of the career - Stepping stone or trap? Working Paper. Gent, Belgium: Universiteit Gent.

Becker, G.S. (1993). Nobel lecture: The economic way of looking at behavior. Journal of Political Economy, 101, $385-409$.

Béduwé, C., \& Giret, J. (2011). Mismatch of vocational graduates: What penalty on French labour market? Journal of Vocational Behavior, 78, 68-79.

Bergstrom, O., \& Storrie, D. (Eds.). (2003). Contingent employment in Europe and the United States. Cheltenham: Edward Elgar.

Bernhardt, A., Morris, M., Handcock, M., \& Scott, M. (2001). Divergent paths: Economic mobility in the new American labor market. New York: Russell Sage.

Borghans, L., \& Golsteyn, B. (2007). Skill transferability, regret and mobility. Applied Economics, 39, 1663-1678.

Bryk, A., \& Raudenbush, S. (1992). Hierarchical linear models. Newbury Park, CA: Sage.

Büchel, F., \& Mertens, A. (2004). Overeducation, undereducation, and the theory of career mobility. Applied Economics, 36, 803-816.

Burke, R. (1997). Correlates of underemployment among recent business school graduates. International Journal of Manpower, 18, 627-635.

Carroll, D., \& Tani, M. (2013). Over-education of recent higher education graduates: New Australian panel evidence. Economics of Education Review, 32, $207-218$.

Daly, M., Buchel, F., \& Duncan, G. (2000). Premiums and penalties for surplus and deficit education: Evidence from the United States and Germany. Economics of Education Review, 19, 169-178.

de Grip, A., Bosma, H., Willems, D., \& van Boxtel, M. (2008). Job-worker mismatch and cognitive decline. Oxford Economic Papers, 60, $237-253$.

de Vries, M.R., \& Wolbers, M.H. (2005). Non-standard employment relations and wages among school leavers in the Netherlands. Work, Employment E Society, 19 , $503-525$.

Doeringer, P.B., \& Piore, M.J. (1971). Internal labor markets and manpower analysis. Lexington: Heath Lexington Books.

Dolton, P., \& Vignoles, A. (2000). The incidence and effects of overeducation in the U.K. graduate labour market. Economics of Education Review, $19,179-198$.

Dooley, D., Prause, J., \& Ham-Rowbottom, K.A. (2000). Underemployment and depression: Longitudinal relationships. Journal of Health and Social Behavior, 41, 421-436.

Dunlap, W.P., Chen, RunSan, \& Greer, T. (1994). Skew reduces test-retest reliability. Journal of Applied Psychology, 79, $310-313$.

Edwards, J.R. (1991). Person-job fit: A conceptual integration, literature review, and methodological critique. In C. Cooper (Ed.), International review of industrial and organizational psychology, Vol. 6. (pp. 283-357). Chichester, UK: Wiley.

European Commission (2014). Tackling the gender pay gap. Luxembourg: Publications Office of the European Union. 
Feldman, D.C. (1996). The nature, antecedents, and consequences of underemployment. Journal of Management, 22, $385-409$.

Feldman, D.C., Leana, C.R., \& Bolino, M.C. (2002). Underemployment and relative deprivation among reemployed executives. Journal of Occupational and Organizational Psychology, 75, 453-471.

Feldman, D.C., \& Turnley, W.H. (1995). Underemployment among recent business college graduates. Journal of Organizational Behavior, 16, 691-706.

Goodman, J.S., \& Blum, T.C. (1996). Assessing the non-random sampling effects of subject attrition in longitudinal research. Journal of Management, 22, 627-652.

Greenhalgh, C., \& Mavrotas, G. (1996). Job training, new technology and labour turnover. British Journal of Industrial Relations, 34, $131-150$.

Heijke, H., Meng, C., \& Ris, C. (2003). Fitting to the job: The role of generic and vocational competencies in adjustment and performance. Labour Economics, 10, $215-229$.

Heslin, P. (2005). Conceptualizing and evaluating career success. Journal of Organizational Behavior, 26, 113-136.

Hox, J. (2002). Multilevel analysis: Techniques and applications. Mahwah, NJ: Lawrence Erlbaum Associates.

Kristof-Brown, A., Zimmerman, D., \& Johnson, E. (2005). Consequences of individuals' fit at work: a meta-analysis of person-job, person-organization, person-group, and person-supervisor fit. Personnel Psychology, 58, 281-342.

Lam, S., Ng, T., \& Feldman, D. (2012). The relationship between external job mobility and salary attainment across career stages. Journal of Vocational Behavior, 80, $129-136$.

Latack, J.C., Kinicki, A.J., \& Prussia, G.E. (1995). An integrative process model of coping with job loss. Academy of Management Review, 20, 311-342.

Lawrence, B. (1988). Age grading: The implicit organizational timetables. Journal of Occupational Behavior, 30, $330-346$.

MacKinnon, D.P. (2008). Introduction to statistical mediation analysis. New York, NY: Taylor \& Francis/Lawrence Erlbaum.

McCormick, B. (1990). A theory of signalling during job search, employment efficiency, and "stigmatised" jobs. Review of Economic Studies, 57, $299-313$.

McKee-Ryan, F.M., \& Harvey, J. (2011). "I have a job but...": A review of underemployment. Journal of Management, 37, 962-996.

Meng, C. (2006). Discipline-specific or academic? Acquisition, role and value of higher education competencies. Maastricht: Research Centre for Education and the Labour Market (ROA).

Ministry of Finance (1998). Availability criteria in selected OECD-countries. Danish Ministry of Finance Working Paper 6, Copenhagen.

Ng, T., Eby, L.T., Sorensen, K.L., \& Feldman, D.C. (2005). Predictors of objective and subjective career success: A meta-analysis. Personnel Psychology, 58, 367-408.

Özbilgin, M., Küskü, F., \& Erdoğmuş, N. (2005). Explaining influences on career 'choice': The case of MBA students in comparative perspective. The International Journal of Human Resource Management, 16, 2000-2028.

Pachulicz, S., Schmitt, N., \& Kuljanin, G. (2008). A model of career success: A longitudinal study of emergency physicians. Journal of Vocational Behavior, $73,242-253$.

Paternoster, R., \& Iovanni, L. (1989). The labeling perspective and delinquency: An elaboration of the theory and an assessment of the evidence. Justice Quarterly, 6, $359-394$.

Pedulla, D., \& Newman, K. (2011). The family and community impacts of underemployment. In D. Maynard, \& D. Feldman (Eds.), Underemployment: Psychological, Economic, and Social Challenges (pp. 233-252). New York: Springer.

Pergamit, M.R., \& Veum, J.R. (1999). What is a promotion? Industrial and Labor Relations Review, 52, 581-601.

Prause, J., \& Dooley, D. (1997). Effect of underemployment on school-leavers' self-esteem. Journal of Adolescence, 20, 243-260.

Rosenbaum, J. (1979). Tournament mobility: Career patterns in a corporation. Administrative Science Quarterly, 24, $220-241$.

Sampson, R., \& Laub, J. (1997). A life-course theory of cumulative disadvantage and the stability of delinquency. In T. Thornberry (Ed.), Advances in criminological theory, Vol. 7. (pp. 133-161). New Brunswick, N.J.: Transaction Publishers.

Scurry, T., \& Blenkinskopp, J. (2011). Underemployment among recent graduates: a review of the literature. Personnel Review, 40, $643-659$.

Seibert, S.E., Kraimer, M.L., \& Liden, R.C. (2001). A social capital theory of career success. Academy of Management Journal, 44, $219-237$.

Spivey, C. (2005). Time off at what price? The effects of career interruption on earnings. Industrial and Labor Relations Review, 59, 119-140.

Spurk, D., Abele, A., \& Volmer, J. (2011). The career satisfaction scale: Longitudinal measurement invariance and latent growth analysis. Journal of Occupational and Organizational Psychology, 84, 315-326.

Thompson, K., Shea, T., Sikora, D., Perrewé, P., \& Ferris, G. (2013). Rethinking underemployment and overqualification in organizations: The not so ugly truth. Business Horizons, 56, 113-121.

Tsai, Y. (2010). Returns to overeducation: A longitudinal analysis of the U.S. labor market. Economics of Education Review, $29,606-617$.

Valcour, M., \& Ladge, J. (2003). Family and career path characteristics as predictors of women's objective and subjective career success: Integrating traditional and protean career explanations. Journal of Vocational Behavior, 73, 300-309.

Verbruggen, M., \& Sels, L. (2010). Social-cognitive factors affecting clients' career and life satisfaction after counseling. Journal of Career Assessment, 18, 3-15.

Verhaest, D., \& Omey, E. (2009). Objective over-education and worker well-being: A shadow price approach. Journal of Economic Psychology, $30,469-481$.

Verhaest, D., \& Omey, E. (2010). The determinants of overeducation: Different measures, different outcomes? International Journal of Manpower, 31, 608-625.

Verhaest, D., Sellami, \& Van der Velde (2015). Differences in horizontal and vertical mismatches across countries and fields of study. International Labour Review (in press).

Wanous, J.P., Reichers, A.E., \& Hudy, M.J. (1997). Overall job satisfaction: How good are single-item measures? Journal of Applied Psychology, 82, $247-252$.

Wooden, M., Warren, D., \& Drago, R. (2009). Working time mismatch and subjective well-being. British Journal of Industrial Relations, $47,147-179$. 